\title{
The Impact of Exchange Rate on Market Fundamentals: A Case Study of J-curve Effect in Vietnam
}

\author{
Nguyen Quang My ${ }^{1}$, Mustafa Sayim ${ }^{1, *} \&$ Hamid Rahman ${ }^{1}$ \\ ${ }^{1}$ California School of Management, Alliant International University, 10455 Pomerado Rd, \\ San Diego, CA, 92131, United States \\ *Corresponding author: California School of Management, Alliant International University, \\ 10455 Pomerado Rd, San Diego, CA, 92131, United States. E-mail: msayim@alliant.edu
}

Received: March 13, 2017 Accepted: January 24, 2017 Published: March 27, 2017

doi:10.5296/rae.v9i1.11019 URL: https://doi.org/10.5296/rae.v9i1.11019

\begin{abstract}
This study examines if there is an equilibrium relationship between gross domestic product (GDP), exchange rate fluctuation and trade balance in long-term and short-term in Vietnam. The results show that the short-term and long-term exchange rate fluctuations impact the trade balance in Vietnam; both ARDL (Autoregressive Distributed Lag) and ECM (Error Correction Model) methodologies implied that exchange rate has a statistically negatively impact on the trade balance. Particularly, Autoregressive distributed lag (ARDL) utilized to test the long -term impact, shows the trade balance deficit becomes worse when the REER (real effective exchange rate) increases. ECM (Error Correction Model) equation based on the long-term cointegration equation and impulse response, reveals that the domestic currency devaluation could not improve the trade balance, indicating that the J-curve effect does not hold on the dong, the currency of Vietnam.
\end{abstract}

Keywords: Exchange rate, J-Curve, Trade balance, GDP, Domestic currency devaluation, ARDL, ECM. 


\section{Introduction}

After "the reversal of the socialist industrialization model giving priority to heavy industry, and placing a new emphasis on agriculture and light industry" in 1990s, a more decisive economic reform under the renovation (Doi Moi Policy) laid the basis for Vietnam's accession to ASEAN in 1995, AFTA's trade liberalization and APEC in 1998 (Van Hoa, 1997). As a result, these expanding their trading with the international community and meliorating the diplomatic relations with US led to the becoming a member of WTO (World Trade Organization) in 2006. It was highlighted that the BTA (bilateral trade agreement) between US and Vietnam in 2000, which made from the condition of most favored nation (MFN) trade status, to a permanent normal trade relations (PTNR). After 2000s, the trade flows between US and Vietnam grew quickly, from $\$ 368$ mil to $\$ 3,108$ mil of exports and $\$ 822$ mil $\$ 12,290$ mil of imports (International Trade Commission) (Martin, 2011). According to the Observatory of Economic Complexity and Vietnam Customs, after 2011, Vietnam had the surplus in trade balance for instance in 2012 (\$0.3 bn), 2013 (\$0.86 bn) and 2014 (\$2 bn). In addition, the export volume from Vietnam to the USA; according to the US census (United State Census Bureau), has been increased from \$821.3 mil (2000) to \$37,993 mil (2015); specifically, from 2012 to 2015 volume has been raised from $\$ 20,267$ million to $\$ 37,993$ million or $87.46 \%$ in percentage term. Vietnam has rapidly risen to become a significant trading partner for the US, particularly 12th for import in 2016; 6th for deficits; 37th largest destination for US exports; second-largest source of US clothing imports; and a major source for electrical machinery, footwear, and furniture (Martin, 2016). These achievements have been significant compared with damages of the economy after 130 years of Wars (1858-1990) and the hard deeper international integration of Vietnam after a long time of the communist economy. It is obvious that the research paper is unique and valuable not only to explore the emerging development of Vietnam foreign exchange rate, the second integrated Socialist-oriented Market Economy second to China; but also figure out, academically, whether the hard deeper international integration of Vietnam has made the economy more vulnerable to external shocks or not (Leung, 2010).

On the other hand, trade balance is one of the crucial economic factors and has a significant impact on the exchange rate affecting the competitiveness of countries in international trade. In other words, the relationship between the trade balance and exchange rates is important and has to be examined. In addition, a trade balance surplus is expected to increase the GDP (Gross Domestic Product), improve the life standard and stabilize the inflation rate. Therefore, GDP is one of the main indicators having the explanatory power on changes in trade balance. Particularly, increases in the national income level would raise consumptions, which partly leads to demand increases in the marginal propensity to save (MPS). A high inflation rate decreases the value of the domestic currency, which would create an imbalance or net export between export and import. In other words, one unit of the domestic currency could not be enough to cover one unit of the imported goods, which would cause the trade balance deficit. As a result, understanding the short-term and long-term relationships among trade balance, exchange rate and GDP of Vietnam are not only important for policy makers; but also beneficial for international investors, main trading partners such as US, China or Japan; or 
even international researchers.

This research paper also would like to concentrate on the domestic currency devaluation in Vietnam, which could be considered a good tool to stimulate exports and improve the trade balance. Devaluation means lowering the value of a country's currency within a fixed exchange rate system due to the government intervention, by which the monetary authority formally sets a new fixed rate with respect to a foreign reference currency (Krugman, 2008). In fact, this currency policy currently has a positive influence on the trade balance in Vietnam. Since the Doi Moi policies of the 1990s, Vietnamese currency had been devaluated many times such as from 10.000 to 23.000 VND compared to USD (130\%). However, it is difficult to differentiate whether it was a devaluation, which describes a decrease in a currency's value due to internal market forces or changes of other foreign exchange rates. For example, the devaluation of RMB (Renminbi) in 8/2015 led to a depreciation of other currencies in ASIA such as Indonesia, Malaysia, Thailand, Korea and so on...; as a result, Vietnam justified the currency fluctuation margin from 1\%-3\%, which made a trade deficit at the end of 2015 . The response of trade balance to currency devaluation follows a $\mathrm{J}$ shape, called J-curve effect (Davies, 1969). According to the J-curve phenomenon, the domestic currency devaluation would make the trade balance worse over time because of the price effect; yet the quantity effect afterwards would make the trade balance recovers and goes up; as a result, in the immediate and medium terms, trade balance would be deficient. Therefore, this paper investigates the impact of exchange rate fluctuations on Vietnam trade balance in the short term and long term, and whether the exchange rate devaluation improves the trade balance in Vietnam. The results would be used to plan the foundations of appropriate trade policies serving economic growth in the context of globalization and increased international economic integration between Vietnam and the rest of the world. Moreover, researching on the Vietnam foreign exchange rate is supposed to be necessary for US not only to expand its influences on the South East Asian area, but also to understand more the average yearly Vietnamese GDP growth rate of over $6 \%$, second to China; and partly make the better relationships among trading partners in this ASEAN area.

The rest of the research study is organized as follows. Section 2 examines literature review, Section 3 presents data and the methodology, Section 4 evaluates findings, and Section 5 concludes the study.

\section{Literature Review}

\subsection{The Effects Occur as a Devaluated Currency and J-Curve Effect}

Because the flow of goods respond only with time lags to changes in the exchange rate, it is difficult to find arguments about whether "devaluation will improve the trade balance" or not. As a result, "the J-Curve term is used to describe the movement over time of the trade balance: it may deteriorate at first and improvement may come later" (Bahmani-Oskooee, 1985, p. 501). Particularly, when prices of exported goods become cheaper in foreign currency, prices of imported goods become more expensive in basic currency (Davies, 1969). 
Originally, J-curve was "intended to describe the political and economic forces that revitalize some states and push others collapse" (Stewart, 2006). J-curve phenomenon effects were found in other fields of finance, such as private equity investments (Grabenwarter \& Weidig, 2005; Murphy, 2006) and portfolios of venture capital (Meyer \& Mathonet, 2011). Beginning in mid-1980s, J-curve effect was increasingly applied to explore the impacts of devaluations on the relationship between trade balance and exchange rate.

Theoretically, according to Kulkarni and Clarke (2009), a currency devaluation would affect the trade balance in the following 3 stages: immediate impact, medium-term impact and long-term impact. In short-term, the price effect is superior to quantity effect, worsening the trade balance. Exported commodity prices in foreign currency would fall, imported commodity prices in basic currency would rise up, but there would be no increase in export volume; and import volume would not decrease. After the devaluation, importers and exporters would still have to make a signed contract before the depreciation. The price and quantity of the goods would be fixed as commitments before dumping. It is found that the currency devaluation would lead to trade balance's reduction as the importers would need more local currency to pay for imports fixed in volume and priced in foreign currency. Regarding the medium-term impact, quantity effect would gradually change to offset the trade deficit caused by the price effect. New contracts signed after dumping would reflect the relative prices changing in favor of domestic products. After this change, demand would move from foreign goods to domestic products. The above response of exports and imports can be seen soon after the devaluation, however in some cases, it may not prove fully effective for many years. Once this effect begins, the trade balance would improve the bottom position of the J-curve. Related to long-term impacts, the quantity effects would completely overwhelm the price effect; therefore, the trade balance would go up.

\subsection{The Relationships of Trade Balance and Exchange Rate in Developed Countries}

"Most of the papers investigating the J- and the S-Curve phenomena fall into one of the following two broad categories: the earlier papers employing aggregate trade data, and the relatively recent ones employing bilateral trade data" (Bahmani-Oskooee \& Ratha, 2004, p. 1378).

Stucka (2004) explored the long-term and short-term effects of exchange rate on the trade balance in Croatia based on the CPI and PPI data from Q1/1994 to Q2/2002 by using the measurement model ADF test. Cointegration tests in ARDL method has been found to impact exchange rates on trade balances. As a result, there was a $1 \%$ decline in the long-term impact on the equilibrium of the trade balance in the range of $0.94 \%$ to $1.3 \%$; in addition, the authors also found evidence of J-curve effect.

The results from studies conducted in Japan showed that there is a tendency to support both the positive impact of exchange rate depreciation on trade balance in long run, as well as the J- curve effect. Specifically, Anju and Uma (1999) used quarterly data from 1975 to 1996 and the Johansen method to find a relationship in the long-term between trade balance, exchange rate, and GDP. The study suggested that the devaluation of exchange rate leads to trade balance improvement. Furthermore, by assessing Error Correction Model (ECM) as well as 


\section{MInstitute ${ }_{\text {Mink }}^{\text {Macrothink }}$}

impulse response, they have proved the existence of the J-curve effect. In estimations, initially, the trade balance worsened in 5 quarters, then improved and reached a new equilibrium in the next 13 quarters. An earlier study by Marcus Noland (1989) on the economy in Japan, with quarterly data during the period from 1970 to1985, also supported these findings. Specifically, the results showed that the estimated price elasticity in the long-term met the Marshall - Lerner condition and implied the exchange rate devaluation improved the trade balance in the long term. J curve effect was also found, indicating that it took 7 quarters from the devaluation moment; therefore, the trade balance began to improve; and it reached a new equilibrium after 16 quarters.

Unlike Japan, where studies showed a clear trade balance improvement in the long term, as well as the existence of J-curve pattern, U.S. study results were not clear. Rose and Yellen (1989) utilized quarterly data for the period from 1960 to 1985 at the bilateral level between the United States and six major trade partners of the U.S. They found no J curve or long-term relation between the exchange rate and bilateral trade flows. On the other hand, Marwah and Klein (1996) also studied the effect of bilateral exchange rates on the bilateral trade balance in the U.S. and Canada with their key trading partners (quarterly data from 1977 to 1992). They asserted after currency devaluation, trade balance, both in the U.S. and Canada, complied with S-curve model, i.e. initially, the trade balance shaped J-curve but tended to be bad at the end of the period. Another study by Mohsen Bahmani - Oskoee and Zohre Ardalani (2006) re- focused on estimating the functions of exports and imports respectively at the industrial level in the U.S. They used the autoregressive distributed lag (ARDL) to analyze cointegration, a method developed by Pesaran, Shin, and Smith (2001). The results showed that of half the 66 export functions estimated for the U.S. industries, the coefficient of the exchange rate was significantly positive as expected. However, in the field of import only 13 of the 66 cases had the positive exchange rate coefficient as expected. Thus, this study showed that if the general data is used, the significant coefficient of the exchange rates in some areas may be offset by the insignificant coefficients of the other fields and can lead to the wrong conclusion that the exchange rate does not affect trade flows.

\subsection{The Relationships of Trade Balance and Exchange Rate in Developing Countries}

It is widely observed that the domestic currency devaluation to stimulate the export volume is more popular in developing countries. Occasionally, these countries consider export orientation as the key policy to improving GDP and controlling inflation. However, it does not mean that the devaluation would make the trade balance better in the long-term in all of the developing countries.

Particularly, by using the transformed regression model of Wickens and Breusch (1988), Upadhyaya and Dhakal (1997) tested the impact of devaluation on the trade balance in 8 developing countries in Asia, Europe, Africa and Latin America; yet they found that only in Mexico, exchange rate devaluation improved the trade balance in the long term. In Latin America, "there is evidence of a J-curve for Chili, Ecuador, and Uruguay and lack of support for a J-curve for Argentina, Brazil, Colombia, and Peru" (Hsing, 2008). Another research paper by Wilson (2001) examined the relation between trade balance and real exchange rates 
in the bilateral trade of Singapore, South Korea and Malaysia with the U.S. and Japan, but found no evidence of the J-curve effect except between South Korea and the United States. Even, according to Rose (1990), in a number of developing countries, "a depreciation of the real exchange rate is not strongly associated with a significant improvement in the trade balance" (p. 1). Consequently, it was supposed that "the conventional wisdom to pursue real depreciation to improve the trade balance may not apply to" some developing countries (Hsing, 2008).

On the other hand, against the viewpoints of Wilson (2001), Lal and Lowinger found that "the J-curve pattern of the trade balances has been confirmed for six out of seven countries" consisting of four developing countries including Indonesia, Malaysia, the Philippines, and Thailand (2002, p. 410). Some research papers tried to explore deeper relationships between the exchange rate and trade balance in Thailand and Malaysia. Bahmani-Oskoose and Kanitpong (2001) tested quarterly discrete data between Thailand and 5 major trading partners (Germany, Singapore, Japan, UK, and U.S.) from 1973 to 1990. By using ARDL, they found evidence of the J-curve effect in bilateral trade with the U.S. and Japan only. In another study on the relationships between exchange rate and trade balance from 1955 to 2006, Har and Tan (2008) used annual data, VECM (Vector Error Correction model), unit testing experience, and associated technical co Engle - Granger to test a Malaysia case. The authors found that the real exchange rate was an important variable affecting the trade balance and there was no presence of the J-curve in the case of Malaysia.

Hardly do researchers concentrate on this topic, and it seems that these studies were not officially published and written in Vietnamese. Lord's study is one of the few official publications on the impact of real exchange rate on export in Vietnam, yet is not related to devaluation and J-curve effects. Lord (2002) used ECM model to calculate the elasticity of footwear exports to the real exchange rate in the short and long term. The regression results of this study showed that the impact of the real exchange rate on footwear exports had statistical significance on the global market and in some regional markets. Three unofficial studies about this topic are regarded as significant contributions to this field including Pham Hồng (2009), Dao and Trinh (2010); and Hoàn \& Hào (2011). However, Phạm Hồng presented a seminar with a good literature review, and Dao and Trinh wrote a qualitative research paper, which focused on explaining relationships between exchange rate and trade balance. Hoàn \& Hào's study used the cointergration theory and error correction model (ECM) for quarterly data series to test the effects of the real exchange rate on the trade balance in long-term and short-term in Vietnam from 1995 to 2004; although there were also some weaknesses, such as the non-transparency of calculating REER or the limitation of ECM in identifying relationships in long-term.

This paper tends to use the ARDL cointegration approach of Perasan, Shin, and Smith (2001) to test the effects of exchange rate on trade balance in the long term and error correction model (ECM - Error Correction Model) to explore the effects of exchange rate on trade balance in the short term. Moreover, cointegration analysis hypothesis is commonly applied in analyzing the relation between economic variables in time sequence. Error correction model (ECM) was used in many international studies and considered one of appropriate 
methods to quantify the effect of real exchange rate on export volumes in many countries. It is expected that this combination will not only contribute to the international finance literature, but also shed new lights how currency devaluation impacts the trade balance in developing economies.

\section{Methodology}

\subsection{Hypotheses}

With a concern for deepening the quality of International Finance literature, this study tests two following Hypotheses:

- The trade balance was significantly influenced on the exchange rate and GDP in long-term and short-term.

- Exchange rate devaluation improves the Vietnam trade balance in long-term.

- Vietnam trade balance is significantly followed the J-curve phenomenon.

\subsection{Research Models}

The long-term and short-term relationships between exchange rate and trade balance are tested by the following model:

$$
T B=\alpha+\beta G D P_{d}+\delta R E E R+e
$$

where:

- TB represents trade balance ratio, defined as import over export; this ratio is used to surmount problem taking logarithm in deficit condition. Thus, a decrease in the TB variable implies trade balance improvement.

- GDP $\mathrm{d}$ : real gross domestic products.

- REER: real effective exchange rate.

All above variables are expressed as logarithms. The main objective of the study is to assess the effect of the real exchange rate (REER) on the rate of trade balance (TB); namely whether the real devaluation of currency in the long run will improve trade balance or vice versa currency revaluation would reduce real trade balance. For this purpose, the coefficient on real effective exchange rate (REER) should be positive $(\beta>0)$.

To estimate the impact of the exchange rate on the trade balance, one should control the influence of gross domestic products (GDP), so that the equation (1) may include $\mathrm{GDP}_{\mathrm{d}}$ variable. However, the impact of $\mathrm{GDP}_{\mathrm{d}}$ on TB is not clear, namely an increase of $\mathrm{GDP}_{\mathrm{d}}$ can rise the value of imports, but also can boost exports, so the net effect on TB can be improvement or deterioration, thus $\delta$ can be positive or negative. 


\subsection{Data}

All data in this research paper are expressed in quarterly from 2000 to 2015 to measure the effect of exchange rate and gross domestic products to the trade balance. The data include import and export volumes, real effective exchange rate (REER) of Vietnam that are calculated based on 20 major trading partners, and the Vietnam real GDP. The sources of data are as follows:

- Data on spot exchange rate of Vietnam and 20 major trading partners (against the dollar) are taken from (International Financial Statistic) IFS. The exchange rate is defined as a domestic currency equal to $\mathrm{x}$ foreign currency (indirect method). The commercial partners include: Japan, Singapore, China, South Korea, USA, Thailand, Australia, Hong Kong, Germany, Malaysia, France, Indonesia, UK, Netherlands, Russia, Philippines, Switzerland, Italy, Belgium, and India.

- Data on export and import volume of Vietnam, and Vietnam with 20 major trading partners are collected from the General Statistics Office (GSO) and General Administration of Customs. Data on the Vietnam CPI and its trading partners (2005 as the base year) are taken from IFS and GSO. Data on Vietnam GDPd are taken from DataStream, GSO.

\subsubsection{REER calculation}

Based on the REER calculating of geometrical mean method:

$\mathrm{REER}=(\mathrm{NEERa} / 1 \times \mathrm{RPa} / 1) \mathrm{W} 1 \times(\mathrm{NEERa} / 2 \times \mathrm{RPa} / 2) \mathrm{W} 2 \times \ldots .$.

Where:

- $a$ represents a country that needs to computer REER.

- NEER: the nominal exchange rate $\mathrm{a} / \mathrm{i}$

- Wi: the commercial proportion of each partner in trade (export + import) of a country.

- RP: the correlation of a country's inflation between partner's one.

The formula is modified as follows:

$\operatorname{REER}=\sum_{\mathrm{i}=1}^{\mathrm{n}} \frac{\mathrm{e}_{\mathrm{t}}^{\mathrm{i}}}{\mathrm{e}_{\text {base }}^{\mathrm{i}}} \cdot \mathrm{w}_{\mathrm{t}}^{\mathrm{i}} \cdot \frac{\mathrm{p}_{\mathrm{t}}^{\mathrm{vN}}}{\mathrm{p}_{\mathrm{t}}^{\mathrm{i}}}$

In which:

- ei base: nominal exchange rate of VND against i country`s currency in base year.

- eit: nominal exchange rate of VND against i country`s currency in t year.

- $\mathrm{Pi}_{\mathrm{t}}$ : price index of $\mathrm{i}$ trading partner in $\mathrm{t}$ year.

- Wi: commercial proportion of $\mathrm{i}$ trading partner in $\mathrm{t}$ year.

- $\mathrm{P}_{\mathrm{t}}$ : Vietnam price index in $\mathrm{t}$ year. 


\section{Macrothink}

Where:

$W_{t}^{i}=\frac{I_{i}^{t}+E_{i}^{t}}{\sum_{i=1}^{n}\left(I_{i}^{t}+E_{i}^{t}\right)}$

- $\mathrm{I}_{\mathrm{i}}^{\mathrm{t}}$ : is the import turn-over to Vietnam from the trading partner $\mathrm{i}$ in $\mathrm{t}$ year

- $E_{i}^{t}$ : is the export turn-over of Vietnam to the trading partner $i$ in $t$ year

The exchange rate of VND against i trading partner's currency will be worked out by spot cross-rate. The commercial proportion of $i$ trading partner (Wti) is calculated by dividing the total export and import values of Vietnam against $i$ country at $t$ moment by the total export and import volume of Vietnam against 20 partners at $t$ time.

\subsection{Research Model}

Based on cointegration hypothesis and error correction model (ECM), testing and analyzing method are as follows:

i. Conducting seasonal adjustment for variables of TB, GDP and REER.

ii. Testing stationarity characteristic of the data series by unit root test (ADF).

iii. If the variables are stationary, identify optimal lags of model by 3 features as AIC, SC, and HQ.

iv. Regressing the equation by OLS approach and above optimal lags:

$\Delta \mathrm{TB}_{\mathrm{t}}=\mathrm{a}_{0}+\mathrm{a}_{1} \mathrm{t}+\mathrm{a}_{2} \Delta \mathrm{x}_{\mathrm{t}}+\sum_{\mathrm{i}=1}^{\boldsymbol{\beta}} \mathrm{b}_{1 \mathrm{i}} \Delta \mathrm{TB}_{\mathrm{t}-\mathrm{I}}+\sum_{\mathrm{i}=1}^{\boldsymbol{\beta}} \mathrm{b}_{2 \mathrm{i}} \Delta \mathrm{REER}_{\mathrm{t}-\mathrm{I}}+\sum_{\mathrm{i}=1}^{\boldsymbol{\beta}} \mathrm{b}_{3 \mathrm{i}} \Delta \mathrm{GDP}_{\mathrm{t}-\mathrm{I}}+$

$\mathrm{c}_{1} \mathrm{~TB}_{\mathrm{t}-1}+\mathrm{c}_{2} \mathrm{REER}_{\mathrm{t}-1}+\mathrm{c}_{3} \mathrm{GDP}_{\mathrm{dt}-1}+\mathrm{v}_{\mathrm{t}}$

$\mathrm{v}$. Testing the existence of the long-term equilibrium relationship (cointegration) between the observed variables by Wald-Test in the form of F-test, the relationship is cointegrative if the variables $c_{1}, c_{2}$, and $c_{3}$ in OLS equation differ from 0 .

vi. If cointegration relationship exists, estimating cointegrated vectors (c1, c2, c3) in the above optimal ARDL model.

vii. Analyze short-term fluctuation - ECM model (error correction model) under equation:

$\Delta \mathrm{TB}_{\mathrm{t}}=\alpha_{0}+\Delta \mathrm{TB}_{\mathrm{t}-1}+\Delta \mathrm{REER}_{\mathrm{t}-1}+\mathscr{D E C}_{\mathrm{t}-1}+\varepsilon_{\mathrm{t}}$

viii. Employ impulse response to test reaction of TB against exchange rate fluctuation.

ix. Analyze results

\section{Findings}

\subsection{Conducting Seasonal Adjustment for Variables of TB and GDP}

The study utilized Census X12 to adjust variables of TB and GDP as follows so as to 
eliminate impacts of outliers and seasonal factors.

TB_SA

GDP_SA
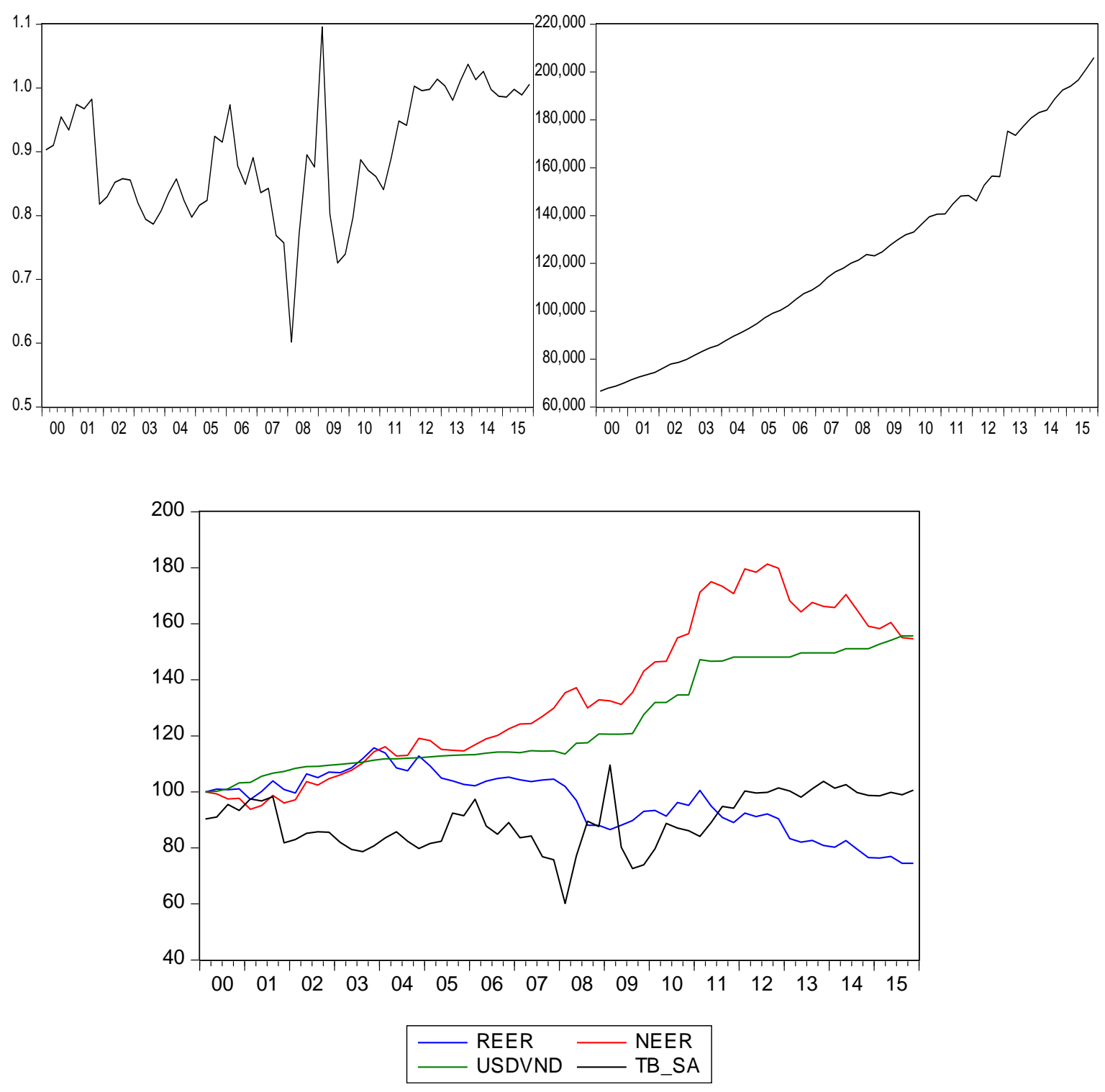

Figure 1. Depicts Logarithm of the Series used in Empirical Analysis

In Vietnam, currency is directly listed as USD/VND; it means that 1 USD is equal to $\mathrm{x}$ VND. The increase of USD/VND shows that the domestic currency devaluation tends to improve export volume. Specifically, if the nominal exchange rate increases, it would make $\mathrm{x}$ up, which leads to a depreciation of VND. However, in reality, the nominal exchange rate (NEER) of VND increases, yet the real change rate (REER) decreases because the inflation rate in Vietnam is higher than other countries. Theoretically, the real exchange rate would significantly influence not only the trade balance, but also the true values of the exported goods in Vietnam. Based on Figure I, the real exchange rate decreases; instead of a decrease, and there was a significant increase of the trade balance in Vietnam. It means that the trade 
balance is significantly influenced by other macro-economic factors such as GDP or inflations. As a result, in this research paper, the calculating of REER includes the impacts of CPI, which is supposed to partly reflect the inflation in Vietnam.

\subsection{Long-Term ARDL Model of Variables}

Long-run relationships between the trade balance ratio (TB); GDP and exchange rate (REER) are studied by the following model:

$\mathrm{X}_{\mathrm{t}}=\left(\mathrm{TB}_{\mathrm{t}}, \mathrm{REER}_{\mathrm{t}}, \mathrm{GDP}_{\mathrm{d}}\right)^{\prime}=\left(\mathrm{TB}_{\mathrm{t}}, \mathrm{X}_{\mathrm{t}}{ }^{\prime}\right)^{\prime}$

Then ARDL is modified as the following OLS (ordinary least squares) equation:

$$
\Delta \mathrm{TB}_{\mathrm{t}}=\mathrm{a}_{0}+\mathrm{a}_{1} \mathrm{t}+\mathrm{a}_{2} \Delta \mathrm{x}_{\mathrm{t}}+\sum_{\mathrm{i}=1}^{\boldsymbol{\beta}} \mathrm{b}_{1 \mathrm{i}} \Delta \mathrm{TB}_{\mathrm{t}-\mathrm{I}}+\sum_{\mathrm{i}=1}^{\boldsymbol{\beta}} \mathrm{b}_{2 \mathrm{i}} \Delta \mathrm{REER}_{\mathrm{t}-\mathrm{I}}+\sum_{\mathrm{i}=1}^{\boldsymbol{\beta}} \mathrm{b}_{3 \mathrm{i}} \Delta \operatorname{GDP}_{\mathrm{t}-\mathrm{I}}+
$$

$\mathrm{c}_{1} \mathrm{~TB}_{\mathrm{t}-1}+\mathrm{c}_{2} \mathrm{REER}_{\mathrm{t}-1}+\mathrm{c}_{3} \mathrm{GDP}_{\mathrm{dt}-1}+\mathrm{v}_{\mathrm{t}}$

In which: $\Delta$ denotes first difference, $\mathrm{t}$ is trend, $\mathrm{p}$ is optimal lag.

According to Pesaran, Shin, and Smith (2001), to measure long-term relationship, it should follow 2 steps. First of all, check the existence of the long-term equilibrium relationship (cointegration) between the observed variables, namely the cointegration vector $\left(c_{1}, c_{2}, c_{3}\right)$. The cointegration relationship between trade balance (TB), real effective exchange rate (REER), and gross domestic product $\left(\mathrm{GDP}_{\mathrm{d}}\right)$ exists if the coefficients $\mathrm{c}_{1}, \mathrm{c}_{2}$, and $\mathrm{c}_{3}$ in equation (2) are different from 0 . Therefore the null hypothesis, starting that there is no long-run equilibrium relationship $\mathrm{H}_{0}$ is tested against an alternative hypothesis $\mathrm{H}_{1}$ :

- $\mathrm{H}_{0}$ (no cointegration): $\mathrm{c}_{1}=\mathrm{c}_{2}=\mathrm{c}_{3}=0$.

- $\mathrm{H}_{1}$ (cointegration): $\mathrm{c}_{1} \neq 0, \mathrm{c}_{2} \neq 0, \mathrm{c}_{3} \neq 0$.

In this step, testing is performed by Wald statistics in form of F-test. If the calculated F-test value is statistically significant, we reject $\mathrm{H} 0$ in favor of $\mathrm{H} 1$, it means that there is a long-term equilibrium relationship between trade balance (TB), real exchange rate (REER), and gross domestic product $\left(\mathrm{GDP}_{\mathrm{d}}\right)$.

Once the cointegration relationship is identified, the next step is to estimate equation (2), i.e. to evaluate cointegration vectors $\left(\mathrm{c}_{1}, \mathrm{c}_{2}, \mathrm{c}_{3}\right)$.

Because the data on trade balance (TB), exchange rate (REER), and gross domestic product (GDPd) are time series, it is necessary to identify an important concept in the time series analyzing process: stationary characteristics. A time series is stationary when the means, variance and covariance (in different lag levels) are the same whenever they are measured. Considering how important a stationary time series is, according to Gujarati (2003), if a time series is not stationary, the study could expose its behavior in the period under consideration. Thus, each time data sample represents only a specific behavior during the considered period and it is impossible to generalize to other periods. For forecast purpose, a non-stationary can be supply no real values. In time-series forecasting, it is always assumed that the trend movement of data in the past and present are maintained for future phase. Moreover, for the 
regression analysis, if time series are not stationary, all the typical results of a classic linear regression analysis will not be valid, and often will be called "fake regression phenomenon". Therefore, the most basic conditions for a time-series forecasting is stationary.

Gujarati (2003) suggests that, it is difficult to separate the stationary and non-stationary time series, thus, normally, we often encounter non-stationary time series due to the trend factor or random nature of time series. It seems to be the nature of the economic variables. Particularly, a time series is non-stationary but its first difference is stationary, denoted as I (1). Therefore, before testing the existence of long-run equilibrium relationship between the variables, one must determine stationary characteristics of observed variables as well as define the optimal lags for the equation (2). Testing stationary characteristics by unit root test (ADF) to determine the optimal lag length for model by 3 criteria as AIC, SC, and HQ.

\subsection{Correlation Matrix}

The correlation matrix showed that REER and GDP have a highly positive relationship; REER and TB have a negative relationship; and TB has a positive relationship with TB.

Table 1. Correlation Matrix

\begin{tabular}{cccc}
\hline Variables & TB & REER & GDP $_{\mathbf{d}}$ \\
\hline TB & - & $\mathbf{- 0 . 5 8 8 3 0 9}$ & $\mathbf{0 . 3 8 0 3 9 1}$ \\
REER & $\mathbf{- 0 . 5 8 8 3 0 9}$ & - & $\mathbf{- 0 . 8 3 0 3 7 2}$ \\
GDPd & $\mathbf{0 . 3 8 0 3 9 1}$ & $\mathbf{- 0 . 8 3 0 3 7 2}$ & -
\end{tabular}

Notes: the result showed that REER and GDP have a highly positive relationship; REER and $T B$ have a negative relationship; and TB has a positive relationship with $T B$.

Testing stationary characteristics of 3-time series by unit root test ADF (Augmented Dickey-Fuller)

Table 2. Statistics for ADF Testing

\begin{tabular}{ccccc}
\hline Variables & $\begin{array}{l}\text { ADF test } \\
\text { Statistic }\end{array}$ & $\begin{array}{c}\text { Critical values } \\
\mathbf{1 \%}\end{array}$ & $\begin{array}{c}\text { Critical values } \\
\mathbf{5 \%}\end{array}$ & $\begin{array}{c}\text { Critical values } \\
\mathbf{1 0 \%}\end{array}$ \\
\hline TB & -0.825378 & -3.555023 & -2.915522 & -2.595565 \\
REER & 0.027569 & -3.538362 & -2.908420 & -2.591799 \\
GDP & 0.170638 & -3.540198 & -2.909206 & -2.592215 \\
$\Delta$ TB & -3.799704 & -3.555023 & -2.915522 & -2.595565 \\
$\Delta$ REER & -7.294986 & -3.540198 & -2.909206 & -2.592215 \\
$\Delta$ GDP & -10.90170 & -3.540198 & -2.909206 & -2.592215 \\
\hline
\end{tabular}

Notes: Variables are taken log $(L)$, (D) (or $\Delta$ ) is first difference of variables'logs. result, $\mid t$-statistic $\mid(A D F$ test $)>\mid$ critical values $1 \% \mid$; thus the time series are stationary 1 result, $\mid t$-statistic $\mid(A D F$ test $)>\mid$ critical values $1 \% \mid$; thus the time series are stationary 1.

Based on the Table 2, it shows that the $|\mathrm{t}|$ values (ADF Test Statistic) being smaller than $|\mathrm{t}|$ values (critical values) in the significance of $1 \%, 5 \%, 10 \%$ equals to the time series are non- 


\section{MInstitute Macrothink $_{\text {Int }}$}

stationary I (0). Then one continues testing stationary characteristics for first differences of the time series, and the $|t|$ value (ADF Test Statistic) being greater than $|t|$ (critical values) in the significance of $1 \%, 5 \%, 10 \%$ means the time series are stationary I (1).

In addition to testing the stationarity, the autocorrelation was implemented among the TB, REER, GDP variables at 1 lag by Granger Causability Testing.

Table 3. The Granger Causability Testing

\begin{tabular}{cccc}
\hline Variables & TB & REER & GDP \\
\hline TB & - & $0.08139(0.7764)$ & $\mathbf{0 . 6 0 3 6 1 ( 0 . 0 4 0 3 )}$ \\
REER & $4.96334(0.0297)$ & - & $0.85293(0.3594)$ \\
GDP & $2.59508(0.0424)$ & $6.80318(0.0115)$ & - \\
\hline
\end{tabular}

Notes: The results show that REER, GDP and TB have good relationships with each other.

The results in Table 3 indicated F-Statistic values and corresponding p-values (in parentheses) between pairs of variables. Accordingly, the results show that the REER variable affects GDPd and TB, TB variable affects GDPd and REER.

\subsection{Optimal Lag Length for Variables}

Model's lag length (3 variable relationships of TB, REER and GDPd) is measured based on one of three criteria such as: AIC (Akaike info criterion), SC (Schwarz Criterion), and HQ (Hannan-Quinn criterion). The optimal lag length is determined when the AIC, SC, HQ values are smallest (Table 4). Using 3 criteria simultaneously helps reinforce the selection of optimal lag length. The lag length is from 1 to $8(\mathrm{p}=1, . ., 8)$. It means the correlation of $\mathrm{TB}$, REER and GDPd are considered under 8 quarterlies. Based on Table III, the optimal lag number of three variables TB, GDP and REER is one $(p=1)$. It means that after 1 quarter, the exchange rate and GDP fluctuations affects the trade balance.

Table 4. Optimal Lag Length of Three Variables

\begin{tabular}{ccccccc}
\hline Lag & LogL & LR & FPE & AIC & SC & HQ \\
\hline $\mathbf{0}$ & 136.6964 & NA & $1.69 \mathrm{e}-06$ & -4.774873 & -4.666372 & -4.732807 \\
$\mathbf{1}$ & 346.0729 & $388.8421^{*}$ & $1.32 \mathrm{e}-09^{*}$ & $-11.93118^{*}$ & $-11.49717^{*}$ & $-11.76291^{*}$ \\
$\mathbf{2}$ & 353.8838 & 13.66903 & $1.38 \mathrm{e}-09$ & -11.88871 & -11.12920 & -11.59425 \\
$\mathbf{3}$ & 359.1495 & 8.650808 & $1.59 \mathrm{e}-09$ & -11.75534 & -10.67033 & -11.33468 \\
$\mathbf{4}$ & 362.3129 & 4.857980 & $1.99 \mathrm{e}-09$ & -11.54689 & -10.13638 & -11.00004 \\
$\mathbf{5}$ & 370.3170 & 11.43453 & $2.11 \mathrm{e}-09$ & -11.51132 & -9.775307 & -10.83827 \\
$\mathbf{6}$ & 373.4496 & 4.139418 & $2.70 \mathrm{e}-09$ & -11.30177 & -9.240252 & -10.50252 \\
$\mathbf{7}$ & 382.8048 & 11.35988 & $2.80 \mathrm{e}-09$ & -11.31446 & -8.927434 & -10.38901 \\
$\mathbf{8}$ & 391.6952 & 9.842992 & $3.01 \mathrm{e}-09$ & -11.31054 & -8.598018 & -10.25890 \\
\hline
\end{tabular}

Notes: Table 4 indicated lag order selected by the criterion, in which LR stands for sequential modified LR test statistic (each test at 5\% level); FPE is Final prediction error; AIC is Akaike information criterion; SC is Schwarz information criterion; and HQ is Hannan-Quinn information criterion. The optimal lag number of three variables TB, GDP and REER is one $(p=1)$. 


\section{Macrothink}

4.5 Testing the Existence of Cointegration Relationship between Variables

\subsubsection{OLS Test}

In Table 5 an OLS test was implemented to examine the equation (2), in cases with or without a linear trend $\left(a_{1}=0, a_{1} \neq 0\right)$. The general ARDL model is following:

$$
\begin{aligned}
& \Delta \text { LTB }_{t}=a_{0}+b_{11} \Delta \text { LTB }_{t-1}+b_{21} \Delta \text { LREER }_{t-1}+b_{31} \Delta \text { LGDP }_{t-1}+c_{1} \text { LTB }_{t-1}+ \\
& c_{2} \text { LREER }_{t-1}+c_{3} \text { LGDP }_{t-1}+e_{t}
\end{aligned}
$$

Table 5. OLS Test of Three Variables

\begin{tabular}{ccccc}
\hline Variable & Coefficient & Std. Error & t-Statistic & Prob. \\
\hline C & 0.946360 & 1.491082 & 0.634680 & 0.5283 \\
$\Delta$ LTB(t-1) & -0.014354 & 0.141727 & -0.101279 & 0.9197 \\
$\Delta$ LREER(t-1) & -0.338467 & 0.377797 & -0.895897 & 0.3742 \\
$\Delta$ LGDP(t-1) & -0.695044 & 0.701485 & -0.990817 & 0.3261 \\
LTB(t-1) & -0.402513 & 0.129208 & -3.115231 & 0.0029 \\
LREER(t-1) & -0.209540 & 0.197571 & -1.060577 & 0.2935 \\
LGDP(t-1) & -0.002212 & 0.057858 & -0.038236 & 0.9696 \\
R-squared & 0.218777 & Mean dependent var & 0.001616 \\
Adjusted & 0.133553 & S.D. dependent var & 0.083115 \\
R-squared & 0.077366 & Akaike info criterion & -2.174530 \\
S.E. of regression & Schwarz criterion & -1.934369 \\
Sum squared resid & 0.329204 & Hannan-Quinn criter. & -2.080237 \\
Log likelihood & 74.41042 & Hats & \\
F-statistic & 2.567074 & Durbin-Watson stat & 2.027975 \\
Prob(F-statistic) & 0.029005 & & \\
\hline Notes: The table shows probabilities of the VAR model (3). The result \\
showed that this equation may be in serial correlation. Consequently, a \\
Breusch-Godfrey Serial Correlation LM test was implemented. \\
\hline
\end{tabular}

According to Pesaran, Shin, and Smith (2001), error of this equation may be not serial independent; thus it would have some impacts on choosing the lag of the model. As a result, a Breusch-Godfrey Serial Correlation LM test is supposed to be important to examine:

$\mathrm{H}_{0}$ : errors are not in serial correlation

$\mathrm{H}_{1}$ : errors are in serial correlation

Table 6. Breusch-Godfrey Serial Correlation LM Test

\begin{tabular}{cccc}
\hline \multicolumn{4}{c}{ Breusch-Godfrey Serial Correlation LM Test } \\
\hline F-statistic & 1.150010 & Prob. F(1,54) & 0.2883 \\
Obs*R-squared & 1.292849 & Prob. Chi-Square(1) & 0.2555 \\
\hline Notes: The results of the Breusch-Godfrey Serial Correlation LM Test \\
showed that equation (3) have errors are not in serial correlation. \\
\hline
\end{tabular}




\section{Al Macrothink}

Based on the Table 6 , p-value $=0.2555>5 \%$, which means that $\mathrm{H}_{0}$ is accepted that there is no serial correlation.

\subsubsection{Wald Test}

Conducting Wald-Test with 2 hypotheses:

$\mathrm{H}_{0}: \mathrm{c}_{1}=\mathrm{c}_{2}=\mathrm{c}_{3}=0$

$\mathrm{H}_{1}: \mathrm{c}_{1} \neq \mathrm{c}_{2} \neq \mathrm{c}_{3} \neq 0$

The 1 lag is used in Wald-Test for the question whether the cointegration relationship between variables in the equation (3) exists or not (Table 7). Based on Wald-Test, p-value (probability) $=0.02<0.05$ meaning the null hypothesis $\mathrm{H}_{0}$ is rejected and the $\mathrm{H}_{1}: \mathrm{c}_{1} \neq \mathrm{c}_{2} \neq \mathrm{c}_{3}$ $\neq 0$ is accepted. Moreover, $\mathrm{F}=5.85$ is higher than the $\mathrm{F}_{5 \%}-4.11$. In other words, there is the cointegration relationship between the TB, REER, and GDP variables.

Table 7. Wald Test

\begin{tabular}{|c|c|c|c|}
\hline \multicolumn{4}{|c|}{ Wald Test } \\
\hline Test Statistic & Value & df & Probability \\
\hline F-statistic & 3.503146 & $(3,55)$ & 0.0213 \\
\hline Chi-square & 10.50944 & 3 & 0.0147 \\
\hline \multicolumn{4}{|c|}{ Null Hypothesis: $C(1)=C(2)=C(3)=0$} \\
\hline \multicolumn{4}{|c|}{ Null Hypothesis Summary } \\
\hline \multicolumn{2}{|c|}{ F-statistic } & $95 \%$ & $97.5 \%$ \\
\hline \multirow{2}{*}{\multicolumn{2}{|c|}{5.853307}} & $\mathbf{I}(\mathbf{0}) \quad \mathbf{I}(\mathbf{1})$ & $\begin{array}{llll}I(0) & I(1) & I(0) & I(1)\end{array}$ \\
\hline & & $3.15 \quad 4.11$ & $3.88 \quad 4.92 \quad 4.816 .01$ \\
\hline \multicolumn{4}{|c|}{$\begin{array}{l}\text { Notes: Restrictions are linear in coefficients. Moreover the } \\
\text { results showed that there is the cointegration relationship } \\
\text { between TB, REER and GDP variables because p-value }<0.05 \text {. }\end{array}$} \\
\hline
\end{tabular}

\subsubsection{Estimating cointegrated vectors (c1, c2, c3)}

The cointegration relationship is found in the above step. The cointegration vectors are estimated by testing ARDL (2) with the optimal lag and $\mathrm{a}_{0}=0, \mathrm{a}_{1}=0, \mathrm{a}_{2}=0$, which measures the impact of exchange rate in trade balance in long-run. The ARDL equation is as followed:

$$
\begin{gathered}
\Delta L T B_{t}=b_{11} \Delta L T B_{t-1}+b_{21} \Delta L R E E R_{t-1}+b_{31} \Delta L G D P_{t-1}+c_{1} L T B_{t-1}+ \\
c_{2} L R E E R_{t-1}+c_{3} L G D P_{t-1}+e_{t}
\end{gathered}
$$

Based on the Table $8, \Delta \operatorname{LTB}(\mathrm{t}-1)$, variables of $\Delta \operatorname{LREER}(\mathrm{t}-1), \Delta \operatorname{LGDP}(\mathrm{t}-1)$ have no statistical meaning; thus they would be taken out of the model. After taking out one by one variables, another ARDL was processed one more time. 
Table 8. Results of ARDL Equation (2) with a1 $=0$, a $2=0$

\begin{tabular}{ccccc}
\hline Variable & Coefficient & Std. Error & t-Statistic & Prob. \\
\hline$\Delta$ LTB(t-1) & -0.034521 & 0.137380 & -0.251278 & 0.8025 \\
$\Delta$ LREER(t-1) & -0.392902 & 0.365965 & -1.073603 & 0.2876 \\
$\Delta$ LGDP(t-1) & -0.758991 & 0.690500 & -1.099190 & 0.2764 \\
LTB(t-1) & -0.365113 & 0.114373 & -3.192286 & 0.0023 \\
LREER(t-1) & -0.088874 & 0.053460 & -1.662446 & 0.1020 \\
LGDP(t-1) & 0.032167 & 0.020224 & 1.590530 & 0.1173 \\
R-squared & 0.213055 & Mean dependent var & 0.001616 \\
Adjusted R-squared & 0.142793 & S.D. dependent var & 0.083115 \\
S.E. of regression & 0.076953 & Akaike info criterion & -2.199490 \\
Sum squared resid & 0.331615 & Schwarz criterion & -1.993639 \\
Log likelihood & 74.18420 & Hannan-Quinn criter. & -2.118668 \\
Durbin-Watson stat & 2.039759 & & &
\end{tabular}

Notes: The results of the model showed that $\triangle L T B(t-1)$, variables of $\triangle L R E E R(t-1), \triangle L G D P(t-1)$ have no statistical meaning; thus they would be taken out of the model.

As a result, the ARDL is followed:

$\Delta L T B_{t}=-0.37 * L T B_{t-1}-0.10 * L R E E R_{t-1}+0.35 * L G D P_{t-1}$

This adjusted ARDL model has the statistical meaning at 5\% with F-statistic $=4.578813$. The cointergrated vector is identified as $\mathrm{c}_{1}=-0.37 ; \mathrm{c}_{2}=-0.10 ; \mathrm{c}_{3}=0.35$ or $(-0.37,-0.1,0.35)$ (Table 9).

Table 9. The ARDL Equation after Adjusting Not Statistical Variables

\begin{tabular}{|c|c|c|c|c|}
\hline Variable & Coefficient & Std. Error & t-Statistic & Prob. \\
\hline LTB(-1) & -0.372281 & 0.100752 & -3.695003 & 0.0005 \\
\hline LREER(-1) & -0.100496 & 0.048716 & -2.062898 & 0.0435 \\
\hline LGDP(-1) & & 0.098576 & 1.920999 & 0.0495 \\
\hline R-squared & 0.185934 & \multicolumn{2}{|c|}{ Mean dependent var } & 0.001713 \\
\hline Adjusted R-squared & 0.158799 & \multicolumn{2}{|c|}{ S.D. dependent var } & 0.082446 \\
\hline S.E. of regression & 0.075617 & \multicolumn{2}{|c|}{ Akaike info criterion } & -2.279832 \\
\hline Sum squared resid & 0.343073 & \multicolumn{2}{|c|}{ Schwarz criterion } & -2.177778 \\
\hline Log likelihood & 74.81470 & \multicolumn{2}{|c|}{ Hannan-Quinn criter. } & -2.239693 \\
\hline Durbin-Watson stat & 1.976726 & & & \\
\hline \multicolumn{5}{|c|}{ Breusch-Godfrey Serial Correlation LM Test } \\
\hline F-statistic & 0.012981 & & $(\mathbf{1 , 5 9 )}$ & 0.9097 \\
\hline Obs*R-squared & 0.013807 & Prob. Chi & -Square(1) & 0.9065 \\
\hline \multicolumn{5}{|c|}{$\begin{array}{l}\text { Notes: } \text { This adjusted ARDL model has the statistical meaning at } 5 \% \text { wt } \\
\text { F-statistic }=4.578813 . \text { The results implied the cointergration vectors } \\
(-0.37,-.01,0.35)\end{array}$} \\
\hline
\end{tabular}




\section{Macrothink}

4.5.4 Identifying the long-term relationships for the equation (1)

The cointergrated vector also showed $\boldsymbol{\beta}=\mathrm{c} 2 /(-\mathrm{c} 1)=-0.27$ and $\boldsymbol{\delta}=0.10$. Consequently, the long-term model with the statistical significance of $5 \%$ is followed:

\section{$L T B=-0.27 L R E E R+0.10 L G D P+0.63$}

According to the information criteria, the optimal model specification is $\operatorname{ARDL}(1,1,1)$. To determine the adjusted model is suitable and reasonable or not, there are some necessary tests should be implemented such as the Redundant Variables Test, LM Serial Correlation Test for the autocorrelation, Heteroscedasticity Test and test the reasonability of the model.

Table 10. The Sequences of Test for the Appropriateness of the Model.

\begin{tabular}{cccc}
\hline \multicolumn{4}{c}{ Breusch-Godfrey Serial Correlation LM Test: } \\
\hline $\begin{array}{c}\text { F-statistic } \\
\text { Obs*R-squared }\end{array}$ & 0.034356 & Prob. F(1, 59) & 0.8536 \\
\hline & 0.036355 & Prob. Chi-Square(1) & 0.8488 \\
\hline Heteroskedasticity Test: White \\
Obs*tatistic & 1.822273 & Prob. F(3,60) & 0.1527 \\
\hline \multicolumn{4}{c}{ The redundant variables test } \\
Specification: LTB LREER LGDP \\
\hline \multicolumn{4}{c}{ Probabilue } \\
t-statistic & 4.326308 & 0.1483 \\
F-statistic & 18.71694 & 0.0001 \\
Likelihood ratio & 16.88410 & 0.0000 \\
\hline
\end{tabular}

Notes: The results showed that there is no autocorrelation, no heteroskedascity and all of the variables are significant at 1\% meaning.

Table 10 showed that the model have the p-value (0.8) of LM Test $>0.05$; the p-value of Heteroskedascity Test is also higher than 0.05 ; it means that there is no autocorrelation and no heteroskedascity phenomenon. Especially, the p-value of the redundant variables test is statistically significant with $1 \%$ meaning three variables are necessary and have their statistical meaning in this model. The result of the long-term model is explained as followings: 


\section{Macrothink}

Table 11. The Depicts of the Long-Term ARDL Model

\begin{tabular}{ccccc}
\hline Variable & Coefficient & Std. Error & t-Statistic & Prob. \\
\hline LREER & -0.275643 & 0.102727 & -2.780613 & 0.0072 \\
LGDP & 0.101246 & 0.039949 & 2.534360 & 0.0139 \\
AR(1) & 0.635798 & 0.099164 & 6.411569 & 0.0000 \\
R-squared & 0.562366 & Mean dependent var & -0.117917 \\
Adjusted R-squared & 0.547779 & S.D. dependent var & 0.110507 \\
S.E. of regression & 0.074313 & Akaike info criterion & -2.314611 \\
Sum squared resid & 0.331346 & Schwarz criterion & -2.212557 \\
Log likelihood & 75.91024 & Hannan-Quinn criter. & -2.274473 \\
Durbin-Watson stat & 2.025543 & & \\
Inverted AR Roots & \multicolumn{5}{c}{.64} & \\
\hline Notes: the results showed that REER, GDP are statistically significant at \\
1\% in the TB model. It means that there is a long-term equilibrium \\
relationship between REER and TB.
\end{tabular}

The assumption of the appropriateness is measured as following:

$\mathrm{H}_{0}: \mathrm{R}^{2}=0$, the model is not appropriate

$\mathrm{H} 1: \mathrm{R}^{2}>0$, the model is appropriate

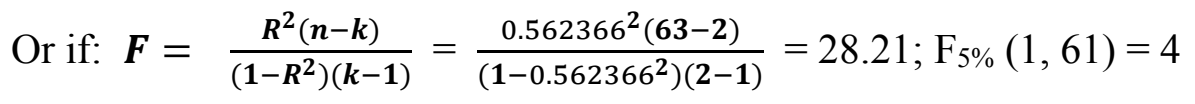

$\mathrm{F} \alpha(\mathrm{k}-1, \mathrm{n}-\mathrm{k})<\mathrm{F}$ with $\mathrm{n}=63, \mathrm{k}=2$ meaning $\mathrm{H}_{0}$ is rejected.

The model explained $56.23 \%$ of the fluctuation of the trade balance, which is as high as expected because trade balance, theoretically, is influenced by other macro-economic factors such as interest rate, FDI, general inflations etc. However, the results showed that REER significantly influence on the trade balance in long-term with $56.23 \%$.

4.5.5 Short - run impact of exchange rate on trade balance: J-curve effect

As stated, the J-curve effect occurs as the domestic currency devaluation in short term will worsen the trade balance but then there is a trade balance improvement in long term. Empirical evidence in some countries also reinforce this theory, but whether J-curve effect exists in the context of Vietnam or not? The existence of the J-curve effects in Vietnam is conducted by evaluating ECM model corresponding to the long-run trade balance equation combined with calculating the impulse response 's trade balance after an exchange rate shock.

4.5.6 ECM approach (Error correction Model)

ECM approach is rewritten as following equation:

$\Delta L T B_{\mathrm{t}}=\alpha_{0}+\Delta L T B_{\mathrm{t}-1}+\Delta L R E E R_{\mathrm{t}-1}+\gamma \Delta L G D P_{\mathrm{t}-1}+\emptyset \mathrm{EC}_{\mathrm{t}-1}+\varepsilon_{\mathrm{t}}$

with $\mathrm{EC}=\mathrm{TB}+0.27$ LREER - 0.1LGDP -0.63 


\section{Mll Macrothink}

Estimating equation (5) by OLS method, the results are reported in Table XI, in which, in short run, REER affects negatively trade balance. 1 percent depreciation in REER leads to 0.36 percent reduction in TB after 1 quarter (lag 1) and vice versa. The result has the statistical significance meaning that there is an equilibrium relationship. The short-term impact of the exchange rate on trade balance is expressed in regression coefficient of $\triangle$ LREER $_{\mathrm{t}-1}$ variable (-0.3648). In summary, the currency devaluation in short-run will worsen the trade balance in Vietnam (Table 12).

Table 12. The Depicts of the ECM Model

\begin{tabular}{ccccc}
\hline Variable & Coefficient & Std. Error & t-Statistic & Prob. \\
\hline C & 0.014384 & 0.015132 & 0.950586 & 0.3458 \\
$\Delta$ LTB $_{\text {t-1 }}$ & -0.034964 & 0.136212 & -0.256690 & 0.7983 \\
$\Delta$ LREER $_{\text {t-1 }}$ & -0.364813 & 0.351494 & -1.037894 & 0.3037 \\
$\Delta$ LGDP $_{\text {t-1 }}$ & -0.748912 & 0.682914 & -1.096641 & 0.2774 \\
EC $_{\text {t-1 }}$ & -0.362773 & 0.113035 & -3.209390 & 0.0022 \\
R-squared & 0.211912 & Mean dependent var & 0.001616 \\
Adjusted R-squared & 0.156608 & S.D. dependent var & 0.083115 \\
S.E. of regression & 0.076330 & Akaike info criterion & -2.230296 \\
Sum squared resid & 0.332097 & Schwarz criterion & -2.058753 \\
Log likelihood & 74.13919 & Hannan-Quinn criter. & -2.162944 \\
F-statistic & 3.831736 & Durbin-Watson stat & 2.033770 \\
Prob(F-statistic) & 0.007942 & & & \\
\hline
\end{tabular}

Notes: the results showed that REER affects negatively to TB in short term. It also showed that there is a statistical equilibrium relationship in short term between three variables.

\subsubsection{Impulse Response}

Impulse response is used to test the improvement of the trade balance over time since impacted by an exchange rate shock (such as currency devaluation). In other words, impulse response also provides an estimation of the $\mathrm{J}$ curve, namely the shape and time of the curve. Time means when the trade balance deteriorates, and improves. Impulse response is calculated by Var unrestricted model.

Table 13 and Figure II showed that the trade balance in Vietnam was impacted by the currency devaluation, yet not following the J-curve. Surprisingly, this study goes against all of the unofficial research papers in Vietnam, which referred that the domestic currency devaluation made trade balance following J-curve phenomenon. The results of EMC and impulse response tests exposed that exchange rate have negative effects on the trade balance. It means the domestic currency devaluation made the trade balance worse following the time. 


\section{Macrothink}

Table 13. Impulse Response of Trade Balance and GDP Following Exchange Rate Shock

\begin{tabular}{cccc}
\hline Period & LTB & LREER & LGDP \\
\hline $\mathbf{1}$ & 0.075617 & 0.000000 & 0.000000 \\
$\mathbf{2}$ & 0.048148 & -0.003290 & 0.000514 \\
$\mathbf{3}$ & 0.030758 & -0.005413 & 0.000847 \\
$\mathbf{4}$ & 0.019751 & -0.006798 & 0.001067 \\
$\mathbf{5}$ & 0.012784 & -0.007716 & 0.001214 \\
$\mathbf{6}$ & 0.008377 & -0.008338 & 0.001316 \\
$\mathbf{7}$ & 0.005590 & -0.008775 & 0.001389 \\
$\mathbf{8}$ & 0.003830 & -0.009094 & 0.001443 \\
$\mathbf{9}$ & 0.002719 & -0.009338 & 0.001487 \\
$\mathbf{1 0}$ & 0.002019 & -0.009537 & 0.001523 \\
\hline
\end{tabular}

Notes: Table 13 and Figure 2 showed that the trade balance in Vietnam was impacted by the currency devaluation, yet not following the J-curve.

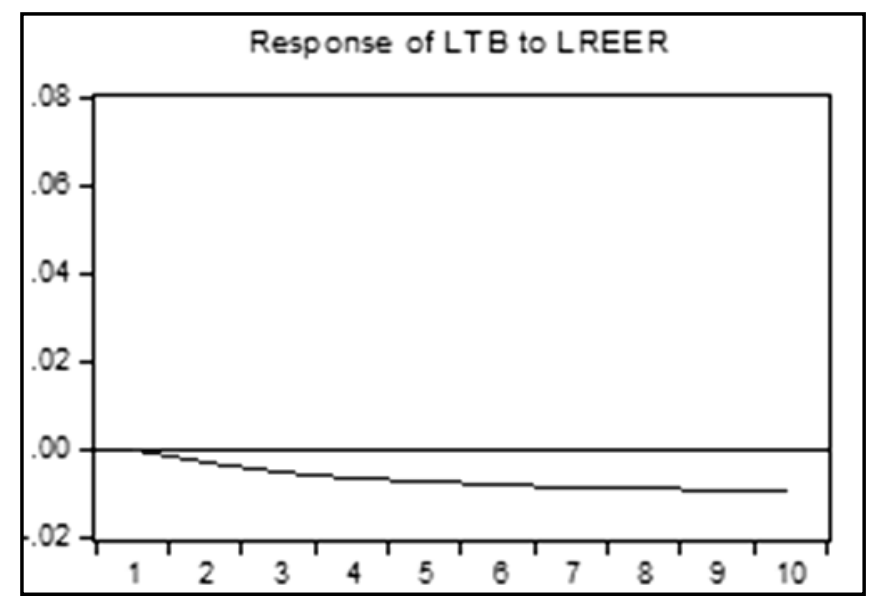

Figure 2. Evolution of Trade Balance Following Real Currency Devaluation

\section{Conclusion}

According to the findings, there is a long-term equilibrium relationship between exchange rate and trade balance; in other words, the study results are statistically significant. It could be recognized that exchange rate has a negative influence on the trade balance, which means that a domestic currency devaluation, in the long-term, would make that trade balance worse. However, that devaluation policy hugely improved the export turn-over, which made the trade balance better in a short period of time. Particularly, in 2015, the trade balance in Vietnam was negative because the VND currency was not strong enough to stand-still throughout big changes in the world, such as the depreciation of RMB. On the other hand, the impact of real GDP on trade balance is positive in long-term, yet negative in short-term. It is necessary to pay attention to the trade balance (TB) ratio in this study, which is measured by imports over exports $(\mathrm{M} / \mathrm{E})$. This means that the purpose of improving exports is good in the long-term, but not good in the short-term. Particularly, improving trade balance would not 
make GDP increase in the short-term, but would make considerable impacts in the long-term. In other word, the fast integration is not balanced and it could make negative impacts in the long-term.

The result also showed that the domestic currency devaluation would make the trade balance worse because $\beta<0$. Based on the data from 2000 to 2015, the results seem to be reasonable because there has been a gap between NEER and REER. Specifically, from 2000-2005, NEER and REER in Vietnam is nearly perfect, with a good increase due to the adjustable currency peg. The State Bank also implemented the domestic currency devaluation from 14.053 VNS/USD to $15.908 \mathrm{VND} / \mathrm{USD}$, about 13.2\%. However, since 2006, these two kinds of exchange rates have markedly differentiation. The decrease of NEER is mainly due to the depreciation of VND compared to USD. The State Bank widened the exchange rate margin to deal with problems of high inflation rate and macroeconomic stabilization. In other words, as stated, NEER increased continuously, which means that VND was made to support international trading; however, conversely, REER has been decreasing because the inflation rate in Vietnam is higher than other countries. It is reasonable to measure REER based on NEER, which is processed through the impacts of CPI, export and import turn-over. On the other hand, the currency policies of Vietnam appear to have considerably improved its turn-over (w). However, it is obvious that not only Vietnam is conducting the domestic currency devaluation policy; other countries are also taking advantages of this to concentrate on promoting their export volume. Moreover, theoretically, should the trade balance improve by the domestic currency devaluation, it would make the value of VND currency (REER) increase throughout the world. It means that the trading and currency policies have still not been inter-correlated to make benefits in the long-term for the whole economy. Another important viewpoint could be the negative impacts of other macro-economic factors, which lessen the domestic currency valuation; because "the macroeconomic policies have to be implemented in order to stabilize and reduce the exchange rates volatilities" (My \& Sayim, 2016, p. 37).

\section{References}

Anju, G. K., \& Uma, R. (1999). Is there a J-curve? A new estimation for Japan. International Economic Journal, 13(4), 71-79. https://doi.org/10.1080/10168739900080029

Bahmani-Oskooee, M. (1985). Devaluation and the J-curve: some evidence from LDCs. The review of Economics and Statistics, 67(3), 500-504. https://doi.org/10.2307/1925980

Bahmani-Oskooee, M., \& Ardalani, Z. (2006). Exchange rate sensitivity of US trade flows: evidence from industry data. Southern Economic Journal, 72(3), 542-559. https://doi.org/10.2307/20111832

Bahmani-Oskooee, M., \& Kantipong, T. (2001). Bilateral J-curve between Thailand and her trading partners. Journal of Economic Development, 26(2), 107-118.

Bahmani-Oskooee, M., \& Ratha, A. (2004). The J-curve: a literature review. Applied 
Economics, 36(13), 1377-1398. https://doi.org/10.1080/0003684042000201794

Dao, H. T. T., \& Trinh, P. T. T. (2010). Mối quan hệ giữa tỷ giá hối đoái và cán cân thanh toán. Retrieved from: http://s3.amazonaws.com/academia.edu.documents/ 36827778/T\%E1\%BB\%B7_gia_va_CCTM.pdf?AWSAccessKeyId=AKIAIWOWYYG Z2Y53UL3A\&Expires $=1490466041 \&$ Signature $=$ rJo6JPusIfrud $\% 2$ Fr6b2L9093dVe0\%3 D\&response-content-disposition $=$ inline $\% 3 \mathrm{~B} \% 20$ filename\%3DT_gia_va_CCTM.pdf

Davies, J. C. (1969). The J-curve of rising and declining satisfactions as a cause of some great revolutions and a contained rebellion. Violence in America, 690-730. New York: Praeger.

Grabenwarter, U., \& Weidig, T. (2005). Exposed to the J-curve: Understanding and managing private equity fund investments. https://doi.org/10.2139/ssrn.646845

Gujarati, D. N. (2003). Basic Econometrics (4 ${ }^{\text {th }}$ ed.). New York: McGraw-Hill.

Hoàn, P. T., \& Hào, N. Đ. (2011). Mối quan hệ giữa tỷ giá hối đoái và cán cân thương mại việt nam thời kỳ 1995-2004. [Online] Retrieved from: http://luanvan.co/luan-van/ moi-quan-he-giua-ty-gia-hoi-doai-va-can-can-thuong-mai-viet-nam-thoi-ky-1995-200449929/

Hsing, Y. (2008). A study of the J-curve for seven selected Latin American countries. Global Economy Journal, 8(4). https://doi.org/10.2202/1524-5861.1438

Krugman, P. R. (2008). International economics: Theory and policy ( $8^{\text {th }}$ ed.). Pearson Education India.

Kulkarni, K., \& Clarke, A. (2009). Testing the J-Curve Hypothesis Case Studies from Around the World. Denver, $\quad$ CO, 2-29. Retrieved from: http://www.kulkarnibooks.com/assets/downloads/kishore_papers/paper_with_andrew_ca lrke_on_J-curve_and_kulkarnihypothesis. pdf.

Lal, A. K., \& Lowinger, T. C. (2002). The J-curve: evidence from East Asia. Journal of Economic Integration, 17(2), 397-415. https://doi.org/10.11130/jei.2002.17.2.397

Leung, S. E. (2010). Vietnam: an economic survey. Asian-Pacific Economic Literature, 24(2), 83-103. https://doi.org/10.1111/j.1467-8411.2010.01261.x

Martin, M. F. (2011). US Vietnam Economic and Trade Relations: Issues for the 112th Congress. DIANE Publishing.

Martin, M. F. (2014). US-Vietnam Economic and Trade Relations: Issues for the 113th Congress. Current Politics and Economics of South, Southeastern, and Central Asia, 23(3/4), $269 . \quad$ Retrieved from: http://search.proquest.com/openview/ce940ce74ad65c34d2ac9607b408cd5b/1?pq-origsi te $=$ gscholar $\& \mathrm{cbl}=2034881$

Martin, M. F. (2016). US-Vietnam Economic and Trade Relations: Issues for the $114 \mathrm{~h}$ Congress. Congressional Research Service. Retrieved from: 
https://fas.org/sgp/crs/row/R41550.pdf

Marwah, K., \& Klein, L. R. (1996). Estimation of J-curves: United States and Canada. Canadian Journal of Economics, 29(3), 523-539. https://doi.org/10.2307/136248

Meyer, T., \& Mathonet, P. Y. (2011). Beyond the J curve: Managing a portfolio of venture capital and private equity funds (Vol. 566). John Wiley \& Sons.

Murphy, D. (2006). Understanding the J-Curve: A Primer on Interim Performance of Private Equity Investments. Strategic Research. Asset Management. Goldman Sachs. Retrieved from:

http://docplayer.net/16491882-Understanding-the-j-curve-a-primer-on-interim-performa nce-of-private-equity-investments.html

My, N. Q., \& Sayim, M. (2016). The Impact of Economic Factors on the Foreign Exchange Rates between USA and Four Big Emerging Countries: China, India, Brazil and Mexico. International Finance and Banking, 3(1), 11. https://doi.org/10.5296/ifb.v3i1.9108

Ng, Y. L., Har, W. M., \& Tan, G. M. (2008). Real exchange rate and trade balance relationship: An empirical study on Malaysia. International Journal of Business and Management, 3(8), 130-137. https://doi.org/10.5539/ijbm.v3n8p130

Noland, M. (1989). Japanese trade elasticities and the J-curve. The Review of Economics and Statistics, 71(1), 175-179. https://doi.org/10.2307/1928067

Pesaran, M. H., Shin, Y., \& Smith, R. J. (2001). Bounds testing approaches to the analysis of level relationships. Journal of Applied Econometrics, 16(3), 289-326. https://doi.org/10.1002/jae.616

Phạm Hồng, P. (2009). Tỷ giá hối đoái thực và cán cân thương mại của Việt Nam. [Online] Retrieved from: http://thuvien.due.udn.vn:8080/dspace/handle/TVDHKT/10905

Rose, A. K. (1990). Exchange rates and the trade balance: some evidence from developing $\begin{array}{llll}\text { countries. Economics 271-275. } & \text { Letters, }\end{array}$ https://doi.org/10.1016/0165-1765(90)90130-S

Rose, A. K., \& Yellen, J. L. (1989). Is there a J-curve? Journal of Monetary Economics, 24(1), 53-68. https://doi.org/10.1016/0304-3932(89)90016-0

Stewart, D. (2006). The J Curve: A New Way to Understand Why Nations Rise and Fall, Ian Bremmer (New York: Simon \& Schuster, 2006), 320 pp., \$26 cloth. Ethics \& International Affairs, 20(04), 537-539. https://doi.org/10.1111/j.1747-7093.2006.00053.x

Stucka, T. (2004). The effects of exchange rate change on the trade balance in Croatia (No. 4-65). International Monetary Fund. https://doi.org/10.5089/9781451848717.001

Upadhyaya, K. P., \& Dhakal, D. (1997). Devaluation and the trade balance: estimating the long run effect. Applied Economics Letters, 4(6), 343-345. https://doi.org/10.1080/135048597355276 


\section{Macrothink}

Research in Applied Economics

ISSN 1948-5433

2017, Vol. 9, No. 1

Van Hoa, T. (Ed.). (1997). Economic development and prospects in the ASEAN: foreign investment and growth in Vietnam, Thailand, Indonesia and Malaysia. Springer. Retrieved from: http://www.jstor.org/stable/25773532?seq=1\#page_scan_tab_contents

Wickens, M. R., \& Breusch, T. S. (1988). Dynamic specification, the long-run and the estimation of transformed regression models. The Economic Journal, 98(390), 189-205. https://doi.org/10.2307/2233314

Wilson, P. (2001). Exchange rates and the trade balance for dynamic Asian economies-does the J-curve exist for Singapore, Malaysia, and Korea? Open Economies Review, 12(4), 389-413. https://doi.org/10.1023/A:1017982901034

\section{Copyright Disclaimer}

Copyright for this article is retained by the author(s), with first publication rights granted to the journal.

This is an open-access article distributed under the terms and conditions of the Creative Commons Attribution license (http://creativecommons.org/licenses/by/3.0/). 